\title{
TEKNIK SUPERVISI PENDIDIKAN OBSERVASI KELAS UNTUK MENINGKATKAN KOMPETENSI MENGAJAR GURU
}

\author{
RAIHANNAH FADILLAH \\ Bimbingan dan Konseling FIP Universitas Negeri Padang \\ Korespondensi: jln. Prof. Dr. Hamka Air Tawar, Padang, Sumatera Barat \\ E-mail :raihannahfadillah99@gmail.com
}

\begin{abstract}
Abstrak : Kepala sekolah adalah tokoh sentral dalam peningkatan mutu pendidikan di sekolah. Berhasil atau tidaknyasebuah lembaga pendidikan khususnya padasatuan pendidikan dan sangat dipengaruhi oleh kompetensi yang dimiliki kepala sekolah tersebut. Teknik supervisi adalah usaha untuk meningkatkan dan mengembangkan sumber daya guru .Dalam setiap kegiatan tentu sekurang-kurangnya ada tiga unsur yang terkait yaitu : 1) jenis atau isi kegiatan, 2) Cara yang digunakan, 3) Orang yang melakukan. Tentu saja masih ada hal-hal yang yang juga dikategorikan sebagai unsur kegiatan misalnya waktu, sarana dan prasarana. Dalam pembicaraan tentang supervisi masih ada hal lagi yang perlu dibicarakan juga sehubungan supervisi yaitu sifat kegiatanya, perlu adanya flash back memory bahwa supervisi adalah suatu kegiatan yang berifat membina dan memberikan bantuan, sehingga "alam " yang tercipta didalamnya harus mendukung terjadinya kegiatan yang betul-betul mencapai tujuannya. Pendapat lain mengatakan bahwa teknik supervisipendidikan adalah alat yang digunakan oleh supervisor untuk mencapai tujuan supervisi itu sendiri yang pada akhirnya dapat melakukan perbaikan pengajaran yang sesuai dengan situasi dan kondisi. Observasi kelas adalah kunjungan yang dialakukan supervisor kesebuah kelas denagn maksud untuk mencermati situasi atau peristiwa yang sedang berlangsung di kelas yang bersangkutan. Usaha dan aktifitas guru-siswa dalam proses pembelajaran. Adapun hal yang perlu diobservasi adalah usaha dan kegiatan gurusiswa dalam hubungan penggunaan bahan dan alat/media pembelajaran, usaha dan kegiatan gurusiswa dalam memperoleh pengalaman belajar,Lingkungan sosial, fisik sekolah, baik di dalam maupun di luar kelas dan faktor-faktor penunjang lainnya. Kompetensi guru merupakan perpaduan antara kemampuan personalia, keilmuan, teknologi, sosial, dan spiritual yang membentuk kompetensi standar profesi guru, yang mencakup penguasaan materi, pemahaman terhadap peserta didik, pembelajaran yang mendidik, pengembangan pribadi dan profesionalitas. Kompetensi guru lebih merujuk pada kemampuan guru untuk mengajar dan mendidik sehingga menghasilkan perubahan perilaku belajar dari peserta didik. Kemampuan guru yang dimaksud adalah tidak hanya dari segi pengetahuan saja tetapi juga dari segi kepribadian, sosial dan profesional sebagai guru.
\end{abstract}

Kata kunci : Kepala sekolah, teknik supervise, observasi kelas, dan kompetensi mengajar guru.

\section{A.LATAR BELAKANG MASALAH}

Pendidikan menempati posisi yang sangat strategis dalam upaya meningkatkan kualitas sumber daya manusia (SDM). Hal tersebut sesuai dengan fungsi dan tujuan pendidikan Nasional yang termuat dalam Undang Undang Nomor 20 Tahun 2003 tentang Sistem Pendidikan Nasional, Pasal 3 sebagai berikut : "Pendidikan Nasional berfungsi mengembangkan kemampuan dan membentuk watak serta peradaban bangsa 
yang bermartabat dalam rangka mencerdaskan kehidupan bangsa, bertujuan untuk berkembangnya potensi peserta didik agar menjadi manusia yang beriman dan bertaqwa kepada Tuhan Yang Maha, berakhlak mulia, sehat, berilmu, cakap, kreatif, mandiri dan menjadi warga Negara yang demokratis serta bertanggung jawab".

Pendidikan adalah tuntunan di dalam hidup tumbuhnya anak-anak. Adapun maksudnya pendidikan yaitu menuntun segala kodrat yang ada pada anakanak itu, agar mereka sebagai manusia dan sebagai anggota masyarakat dapatlah mencapai keselamatan dan kebahagiaan yang setinggitinngginya. Lembaga pendidikan diciptakan untuk mengantarkan peserta didik dalam meningkatkan perilaku positif, salah satu usaha yang dilakukan melakukan supervisi pendidikan, dimana kegiatan pokok dari supervisi adalah melakukan pembinaan kepada sekolah pada umumnya dan pada guru pada khususnya agar kualitas pembelajarannya meningkat.

Kepala Sekolah berfungsi sebagai pendidik, manager, pengelola, administrator, supervisor, pemimpin, inovator (pembaharuan), motivator (pendorong), pengayom, dan pendamping. Kepala Sekolah mempunyai tugas untuk menyusun rencana dan program membina kesiswaan, pembelajaran, dan ketenagaan, baik menyelenggarakan administrasi sekolah serta membina dan melaksanakan kerja sama/hubungan dengan masyarakat. Penyelenggaraan administrasi sekolah adalah upaya pengaturan dan pendayagunaan segenap sumber daya sekolah (manusia, dana, sarana, dan lingkungan).

Adminitrasi program pengajaran merupakan usaha dan kegiatan yang meliputi pengaturan seperangkat program pengalaman belajar yang disusun untuk mengembangkan kemampuan siswa sesuai dengan tujuan sekolah. Maka dengan demikian tugas Kepala Sekolah selalu menuntut pertanggung jawaban moral dan sikap mental yang dapat terjadi pada pada diri seseorang yang menjadi objek utamanya, oleh sebab itu nilai-nilai pendidikan selalu bersumber dari nilai-nilai budaya yang ada, dimana sekolah terdiri dari beberapa unsur dan kompenenkomponen yang satu sama lainnya saling menunjang dan saling berkaitan, agar sekolah dapat melaksanakan fungsinya sesuai dengan citacita dan harapan masyarakat. Kepala Sekolah merupakan wakil manager dari administrator atasan yang sehari-harinya melaksanakan kepemimpinan di bidang adminitrasi sekolah dan supervisi pendidikan.

Menurut Buku Petunjuk untuk Pembinaan Pendidikan. Tugas-tugas pokok Kepala Sekolah adalah : 1. Kepemimpinan Pengajaran dan Pembinaan Kurikulum. 2. Administrasi Personalia. 3. Bussiness Management. 4. School Plant Management. 5. Hubungan Sekolah Masyarakat. 6. Administrasi Tugas-Tugas Rutin. 7. Pertumbuhan Pribadi, Jabatan Dan Kultur. Mengingat, bahwa tugas dan tanggung jawab Kepala Sekolah adalah cukup besar dan berat, maka hendaknya memperluas hubungan kerjasama, baik di dalam lingkungan sekolah yang dipimpinnya maupun dengan pihak-pihak di luar sekolah terutama para administrasi atasan, para supevisor, para anggota organisasi profesi,dan masyarakat.

Observasi kelas adalah teknik observasi yang dilakukan ketika supervisor yang secara aktif mengikuti jalannya kunjungn kelas ketika proses sedang berlangsung.

a. Tujuannya: 
1. Memperoleh data yang subjektif mengenai aspek situasi dalam proses pembelajaran yang diamati.

2. Mempelajari praktek-praktek pembelajaran setiap pendidik dan mengevaluasinya.

3. Menemukan kelebihan dan sifat yang menonjol pada setiap pendidik.

4. Menemukan kebutuhan para pendidik falam menunaikan tugasnya.

5. Memperoleh bahan-bahan dan informasi guna penyusunan program supervise.

6. Mempererat dan memupuk integritas sekolah.

b. Aspek-aspek yang diobservasi:

Usaha dan aktifitas gurusiswa dalam proses pembelajaran.

c. Cara penggunaan media pembelajaran.

1. Reaksi mental para peserta didik dalam proses pembelajaran.

2. Keadaan media yang digunakan.

3. Lingkungan social, fisik sekolah, baik di dalammaupun di luar kelas dan factor-faktor penunjang lainnya.

d) Alat-alat Observasi:

Check-List, yakni alat yang digunakan untuk mengumpulkan data dalam melengkapi keterangan-keterangan yang lebih obyektif terhadap situasi pembelajaran dalam kelas.

\section{B. PERMASALAHAN}

Berdasarkan hasil penelitian yang dilakukan oleh Sunani mengemukakan kondisi objektif dilapangan menunjukan adanya kelemahan kepala sekolah di bidang supervisi akademik, yaitu: (1) kepala sekolah tidak bisa menunjukan bukti otentik hasil supervisi akademik yang dilakukan secara rutin dan terprogram;(2) kepala sekolah kurang terampil dalam menggunakan model supervisi sehingga tidak dapat menciptakan situasi yang kondusif ketika pelaksanaan supervisi; 3) kurang jelas ada pelaksanaan tindak lanjut supervisi yang telah dilakukan kepala sekolah sehingga hasil supervisi kurang kontributif terhadap peningkatan kemampuan guru dalam melaksanakan pembelajaran.

Sunani, (2014: 34) Hal yang demikian menunjukan bahwa kompetensi supervisi akademik kepala sekolah masih rendah.Fenomena di atas menimbulkan keresahan guru ketika mendengar informasi akan dilaksanakannya supervisi oleh kepala sekolah. Namun demikian, keresahan tersebut mengiringi usaha guru untuk mempersiapkan diri utamanya melengkapi administrasi pembelajaran. Guru sebagai tenaga pengajar yang profesional, potensi dirinya hendaknya terus tumbuh dan berkembang.

Guru setidaknya dapat menyesuaikan diri dengan ilmu pengetahuan dan teknologi. Guru yang profesional itu antara lain, memiliki ciriciri sebagai berikut, yaitu:(1) memiliki kemampuan sebagai ahli dalam mendidik dan mengajar; (2) memiliki rasa tanggung jawab, yaitu mempunyai komitmen dan kepedulian terhadap tugasnya; dan (3) memiliki rasa kesejawatan dan menghayati tugasnya sebagai suatu karir hidup serta menjunjung tinggi kode etik jabatan guru.

Sahertian (2008: 2)Mengapa guru sebagai salah satu komponen sumber daya pendidik memerlukan pelayanan supervisi? Pentingnya bantuan supervisi terhadap guru dapat membantu dalam mengembangkan kemampuan profesionalismenya. Guru setidaknya mampu merencanakan pembelajara, melaksanakan proses pembelajaran yang bermutu, serta mampu melakukan penilaian dan mengevaluasi hasil 
pembelajaran. Sarana dan prasarana dan sistem yang mengatur tata cara.

\section{C.KAJIAN TEORITIS DAN PEMBAHASAN}

\section{a. Supervisi Pendidikan Observasi Kelas}

Menurut Tia Ayum Ningrum,dkk (2019: 428) Kepala sekolah adalah tokoh sentral dalam peningkatan mutu pendidikan di sekolah. Berhasil atau tidaknyasebuah lembaga pendidikan khususnya padasatuan pendidikan dan sangat dipengaruhi oleh kompetensi yang dimiliki kepala sekolah tersebut.

Menurut Mulyasa (2011) kepala sekolah adalah salah satu komponen pendidikan yang paling berperan dalam meningkatkan kualitas pendidikan.Kepala sekolah merupakan manajer sekolah.Sebagai manajer kepala sekolah bertanggung jawab secara langsung untuk memastikan kegiatan dalam sebuah organisasi dijalankan bersama para anggota dari organisasi

Menurut Sule \& Saefullah (2008) Hanya kepala sekolah yang memiliki kompetensi tinggi yang akan memiliki kinerja yang memberi tauladan, menginspirasi dan memberdayakan, kondisi ini akan mendorong perubahan yang bermasyarakat, relevan, efektif biaya serta diterima oleh staf, murid dan masyarakat(Darma, 2007; Hadiyanto, 2004).

\begin{tabular}{llcr}
\multicolumn{2}{c}{ Kompetensi } & manajerial & dan \\
supervisi kepala & sekolah & sangat \\
penting. Jamali \& & Prasojo & $(2013)$
\end{tabular} menyatakan kompetensi manajerial kepala sekolah terhadap prestasi siswa. Kemudian Yogaswara (2010) juga menyatakan bahwa kompetensi manajerial kepala sekolah berkontribusi terhadap kinerja guru. Kompetensi manajerial kepala sekolah terkai dengan menyusun perencanaan sekolah/madrasah, mengembangkan organisasi sekolah/madrasah sesuai kebutuhan,memimpin sekolah/madrasah dalam rangka pendayagunaan sumber daya sekolah/madrasah secara optimal, menciptakan budaya dan iklim sekolah/madrasah yang kondusif dan inovatif bagi pembelajaran dan lai-lain. Kompetensi supervisi terkait dengan pembinaan dan pemberian bantuan dalam memperbaiki kompetensi guru.

\section{Pengertian Teknik Supervisi Pendidikan Observasi Kelas}

Menurut Kamus Besar Bahasa Indonesia "Teknik" secara etimologi adalah Cara (kepandaian dsb) membuat atau melakukan sesuatu yang berhubungan dengan seni, metode atau system mengerjakan sesuatu. Dalam usaha meningkatkan program sekolah, kepala sekolah sebagai supervisor dapat menggunakan berbagai teknik atau metode supervisi pendidikan. Supervisi dapat dilakukan dengan berbagai cara, dengan tujuan agar apa yang diharapkan bersama dapat tercapai.

Pertama-tama perlu adanya kesepakatan tentang makna "teknik" yang digunakan sehubungan dengan kegiatan supervisi. Seperti halnya kegiatan lain, teknik memiliki makna "cara, strategi atau pendekatan". Jadi yang dimaksud dengan teknik supervisi adalah cara-cara yang digunakan dalam kegiatan supervisi.Teknik supervisi adalah usaha untuk meningkatkan dan mengembangkan sumber daya guru (Suharsimi,2004:55).

Dalam setiap kegiatan tentu sekurangkurangnya ada tiga unsur yang terkait yaitu : 1) jenis atau isi kegiatan, 2) Cara yang digunakan, 3) Orang yang melakukan. Tentu saja masih ada hal-hal yang yang juga 
dikategorikan sebagai unsur kegiatan misalnya waktu, sarana dan prasarana. Dalam pembicaraan tentang supervisi masih ada hal lagi yang perlu dibicarakan juga sehubungan supervisi yaitu sifat kegiatanya, perlu adanya flash back memory bahwa supervisi adalah suatu kegiatan yang berifat membina dan memberikan bantuan, sehingga "alam " yang tercipta didalamnya harus mendukung terjadinya kegiatan yang betul-betul mencapai tujuannya.

Observasi kelas adalah kunjungan yang dialakukan supervisor kesebuah kelas denagn maksud untuk mencermati situasi atau peristiwa yang sedang berlangsung di kelas yang bersangkutan.Pendapat lain mengatakan bahwa teknik supervisi pendidikan adalah alat yang digunakan oleh supervisor untuk mencapai tujuan supervisi itu sendiri yang pada akhirnya dapat melakukan perbaikan pengajaran yang sesuai dengan situasi dan kondisi.

Teknik supervisi pendidikan berarti suatu cara atau jalan yang digunakan supervisor pendidikan dalam memberikan pelayanan atau bantuan kepada para guru.Teknik supervise pendidikan merupakan perbaikan pengajaran yang sesuai dengan situasi dan kondisi.

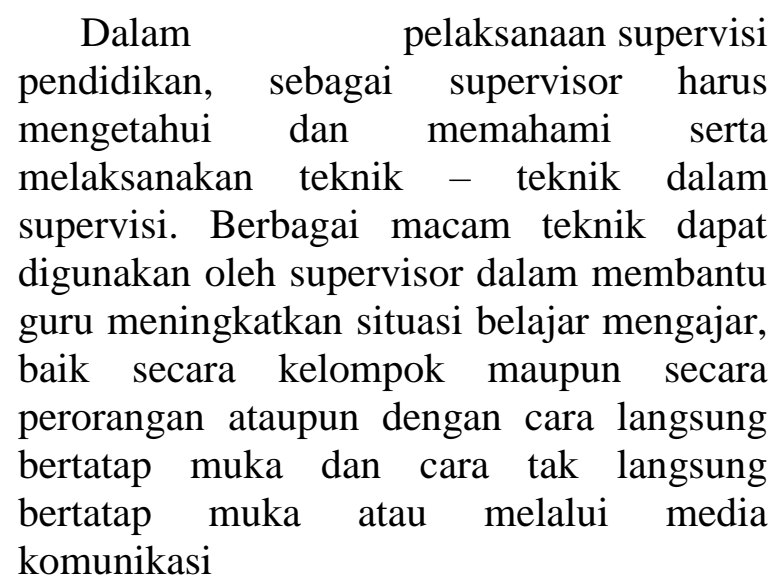

2. Tujuan Teknik Supervisi
Adapun tujuan dari teknik supervise menurut Pramita Surya,dkk (2014:50) adalah:

a. Memperoleh data yang seobjektif mungkin sehingga bahan yang diperoleh dapat digunakan untuk menganalisis kesulitan-kesulitan yang dihadapi guru dalam usaha memprbaiaki hal belajarmengajar.

b. Bagi guru sendiri data yang dianalisis akan dapat membantu untuk mengubah kearah yang lebih baik.

c. Bagi murid-murid sudah tentu akan dapat menimbulkan pengaruh pasotif terhadap kemajuan belajar mereka.

Pendapat lain mengatakan bahwa teknik supervisipendidika $\mathrm{n}$ adalah alat yang digunakan oleh supervisor untuk mencapai tujuan supervisi itu sendiri yang pada akhirnya dapat melakukan perbaikan pengajaran yang sesuai dengan situasi dan kondisi

3. Aspek-aspek yang diobservasi:

a. Usaha dan aktifitas guru-siswa dalam proses pembelajaran.

b. Usaha dan kegiatan guru-siswa dalam hubungan penggunaan bahan dan alat/media pembelajaran.

c. Usaha dan kegiatan guru-siswa dalam memperoleh pengalaman belajar.

d. Lingkungan sosial, fisik sekolah, baik di dalam maupun di luar kelas dan faktor-faktor penunjang lainnya.

Teknik supervisi observasi kelas ini, kepala sekolah sebagai supervisor dapat melakukan pembinaan terhadap para guru melalui diskusi atau percakapan tentang hasil pengamatan supervisi dengan teknik 
observasi kelas, sehingga upaya perbaikan dan peningkatan kualitas kemampuan guru dalam proses pembelajaran dapat tercapai dengan baik.

Dalam hal ini kepala sekolah sebagai supervisor mengadakan peninjauan untuk mengetahui suasana belajar di kelas yang bermaksud menolong guru dirasa kesulitan dalam proses pembelajaran, yang juga sekaligus membantu pertumbuhan kompetensi guru.

Tidak hanya itu saja yang ingin dilihat kepala sekolah pada saat proses supervisi, melainkan juga kepala sekola ingin mengetahui perangkat mengajar yang dipersiapkan oleh guru selama proses pembelajaran. Berpijak pada penjelasan di atas menunjukkan bahwa kepala sekolah telah menyusun program tertulis dan juga menjalankan proses supervisi walaupun belum optimal.

Menurut Shanjina Halim,dkk (2008:165) ada beberapa kritik dan peringatan terkait penggunaan observasi:

1. teknik. Sebagian besar waktu, ditemukan bahwa pengamat tidak sering diberikan

2. pelatihan karena kurangnya dukungan kelembagaan, waktu dan minat. Berikut ini adalah

kelemahan dari observasi kelas:

1. Pengamat umumnya fokus pada perilaku yang terisolasi, tanpa memperhatikan

2. perilaku sebelumnya dan selanjutnya yang mereka rasa memberikan konteks dan

3. makna perilaku. Sangat berisiko memiliki praktik profesional Anda

4. diteliti oleh rekan-rekannya, 'kata Sparks.

Menurut Masoumeh Zaare (2013:607) Mengajar adalah pembelajaran seumur hidup. Salah satu kesenangan mengajar adalah kesempatan untuk jelajahi ide-ide baru dan cara-cara baru mengajar ketika kami mencoba memenuhi kebutuhan kelompok pelajar yang terus berubah. Tetapi kebenaran yang pahit adalah bahwa guru tidak sempurna sekalipun mereka memiliki niat baik dan mencoba yang terbaik untuk melakukan pekerjaan yang mereka bisa, mereka lakukan yaitu Observasi Kelas- Alat yang Kuat Untuk Pengembangan Profesional Berkelanjutan ,Tidak ada kata terlambat untuk mengubah cara kita, sebagai guru, mengajar di kelas.

Kita harus dengan jujur melihat pengajaran kita sendiri untuk bidang-bidang di mana kita mungkin merespons kurang dari idealnya. Kita dapat meminta teman, kolega, dan sesama guru untuk menunjukkan area dimana pengajaran kita perlu tumbuh.

\section{B. Kompetensi Mengajar Guru}

\section{Pengertian Kompetensi Mengajar Guru}

Guru sebagai seseorang yang berwenang untuk mengajar dan mendidik peserta didik harus memiliki kualifikasi dan kompetensi yang baik agar upaya dalam mengkondisikan lingkungan belajar dapat merubah perilaku peserta didik menjadi lebih baik secara efektif dan efisien. Menurut Undang-undang Nomor 14 Tahun 2005 tentang Guru dan Dosen, kompetensi adalah seperangkat pengetahuan, keterampilan, dan perilaku yang harus dimiliki, dihayati, dan dikuasai oleh guru atau dosen dalam melaksanakan tugas keprofesionalan. Kompetensi merupakan syarat yang harus dimiliki guru agar dapat melaksanakan tugas dengan profesional sehingga mencapai tujuan pembelajaran secara efektif dan efisien.

Kompetensi dalam Bahasa Indonesia merupakan serapan dari bahasa Inggris, 
competence yang berarti kecakapan dan kemampuan (Musfah, 2015:27). Kompetensi adalah kumpulan pengetahuan, perilaku, dan keterampilan yang harus dimilki guru untuk mencapai tujuan pembelajaran dan pendidikan. Kompetensi berarti kemampuan mewujudkan sesuatu sesuai dengan tugas yang diberikan kepada seseorang. Kompetensi juga terkait dengan standar dimana seseorang dikatakan kompeten dalam bidangnya jika pengetahuan, keterampilan, dan sikap serta hasil kerjanya sesuai standar (ukuran) yang ditetapkan dan/atau diakui oleh lembaganya/pemerintah.

Musfah (2015:27) hakikat kompetensi adalah kekuatan mental dan fisik untuk melakukan tugas atau keterampilan yang dipelajari melalui latihan dan praktek. Dari hal ini maka suatu kompetensi dapat diperoleh melalui pelatihan dan pendidikan.

Dalam buku yang ditulis oleh Mulyasa (2013:38) dari seorang tokoh bernama Gordon terdapat enam aspek yang terkandung dalam konsep kompetensi yaitu pengetahuan, pemahaman, kemampuan, nilai, sikap dan minat. Pengetahuan yaitu suatu kemampuan dalam aspek kognitif, contohnya guru mengetahui kebutuhan belajar dari peserta didiknya. Pemahaman yaitu kedalaman aspek kognitif dan afektif dimana seorang guru mengetahui pembelajaran yang sesuai dengan karakteristik peserta didik. Kemampuan yaitu dapat melakukan tugas atau pekerjaan yang dibebankan kepada guru dengan disiplin. Nilai yaitu standar perilaku yang diyakini dan tertanam dalam individu setiap guru. Sikap yaitu refleksi dari adanya rangsangan yang datangnya dari luar. Minat yaitu kecenderungan untuk melakukan suatu kegiatan. Maka dapat disimpulkan bahwa kompetensi merupakan kemampuan seseorang yang meliputi pengetahuan, keterampilan, dan sikap, yang dapat diwujudkan dalam hasil kerja nyata yang dapat bermanfaat bagi diri sendiri dan lingkungannya.

Pengertian kompetensi guru berdasarkan Undang-undang Nomor 14 Tahun 2005 adalah kompetensi guru dapat dimaknai sebagai kebulatan pengetahuan, keterampilan dan sikap yang berwujud tindakan cerdas dan penuh tanggung jawab dalam melaksanakan tugas sebagai agen pembelajaran. Menurut Mulyasa (2013:27) Kompetensi guru merupakan perpaduan antara kemampuan personalia, keilmuan, teknologi, sosial, dan spiritual yang membentuk kompetensi standar profesi guru, yang mencakup penguasaan materi, pemahaman terhadap peserta didik, pembelajaran yang mendidik, pengembangan pribadi dan profesionalitas. Kompetensi guru lebih merujuk pada kemampuan guru untuk mengajar dan mendidik sehingga menghasilkan perubahan perilaku belajar dari peserta didik. Kemampuan guru yang dimaksud adalah tidak hanya dari segi pengetahuan saja tetapi juga dari segi kepribadian, sosial dan profesional sebagai guru.

\section{Hal yang Harus Dimiliki Guru}

1. Sikap dasar: postur psikologis yang akan nampak dalam masalahmasalah penting, seperti keberhasilan, kegagalan, pembelajaran, kebenaran, hubungan antar manusia, agama, pekerjaan, permainan dan diri.

2. Bicara dan gaya bicara: penggunaan bahasa sebagai alat berpikir.

3. Kebiasaan bekerja: gaya yang dipakai oleh seseorang dalam bekerja yang ikut mewarnai kehidupannya.

4. Sikap melalui pengalaman dan kesalahan: pengertian hubungan antara luasnya pengalaman dan nilai serta tidak mungkinnya mengelak dari kesalahan. 
5. Pakaian: merupakan perlengkapan pribadi yang amat penting dan menampakkan ekspresi seluruh kepribadian.

6. Hubungan kemanusiaan: diwujudkan dalam semua pergaulan manusia, intelektual, moral, keindahan, terutama bagaimana berperilaku.

7. Proses berpikir: cara yang digunakan oleh pikiran dalam menghadapi dan memecahkan masalah.

8. Perilaku neurotis: suatu pertahanan yang dpergunakan untuk melindungi diri dan bisa juga untuk menyakiti orang lain.

9. Selera: pilihan yang secara jelas merefleksikan nilai-nilai yang dimiliki oleh pribadi yang bersangkutan.

10. Keputusan: keterampilan rasional dan intuitif yang dipergunakan untuk menilai setiap situasi.

11. Kesehatan: kualitas tubuh, pikiran dan semangat yang merefleksikan kekuatan, prespektif, sikap tenang, antusias, dan semangat hidup.

12. Gaya hidup secara umum: apa yang dipercaya oleh seseorang tentang setiap aspek kehidupan dan tindakan untuk mewujudkan kepercayaan itu.

13. Berakhlak Mulia

\section{KESIMPULAN DAN SARAN}

\section{Kesimpulan}

Kepala sekolah merupakan manajer sekolah.Sebagai manajer kepala sekolah bertanggung jawab secara langsung untuk memastikan kegiatan dalam sebuah organisasi dijalankan bersama para anggota dari organisasi.

Menurut Sule \& Saefullah (2008) Hanya kepala sekolah yang memiliki kompetensi tinggi yang akan memiliki kinerja yang memberi tauladan, menginspirasi dan memberdayakan, kondisi ini akan mendorong perubahan yang bermasyarakat, relevan, efektif biaya serta diterima oleh staf, murid dan masyarakat(Darma, 2007; Hadiyanto, 2004).

\begin{tabular}{lcrr}
\multicolumn{2}{c}{ Kompetensi } & manajerial & dan \\
supervisi kepala & sekolah & sangat \\
penting. Jamali \& & Prasojo & $(2013)$ \\
menyatakan kompetensi & manajerial & kepala \\
sekolah terhadap prestasi & siswa. Kemudian \\
Yogaswara & $(2010)$ & juga & \multicolumn{2}{c}{ menyatakan } \\
bahwa kompetensi manajerial kepala \\
sekolah berkontribusi terhadap kinerja guru.
\end{tabular}

$\begin{array}{lrr}\text { Kompetensi } & \begin{array}{c}\text { manajerial } \\ \text { dengan }\end{array} & \begin{array}{r}\text { kepala } \\ \text { menyusun }\end{array} \\ \text { sekolah terkai } & \text { sekolah/madrasah, } \\ \text { perencanaan } & \text { organisasi } \\ \text { mengembangkan } & \text { sesuai } \\ \text { sekolah/madrasah } & \end{array}$

kebutuhan,memimpin sekolah/madrasah dalam rangka pendayagunaan sumber daya sekolah/madrasah secara optimal, menciptakan budaya dan iklim sekolah/madrasah yang kondusif dan inovatif bagi pembelajaran dan lai-lain. Kompetensi supervisi terkait dengan pembinaan dan pemberian bantuan dalam memperbaiki kompetensi guru.

Teknik supervisi adalah usaha untuk meningkatkan dan mengembangkan sumber daya guru (Suharsimi,2004:55).Dalam setiap kegiatan tentu sekurang-kurangnya ada tiga unsur yang terkait yaitu : 1) jenis atau isi kegiatan, 2) Cara yang digunakan, 3) Orang yang melakukan. Tentu saja masih ada halhal yang yang juga dikategorikan sebagai unsur kegiatan misalnya waktu, sarana dan prasarana.

Menurut Aziza Nur Persia, dkk ( 2013)Dalam pembicaraan tentang supervisi masih ada hal lagi yang perlu dibicarakan juga sehubungan supervisi yaitu sifat kegiatanya, perlu adanya flash back memory bahwa supervisi adalah suatu kegiatan yang berifat membina dan memberikan bantuan, 
sehingga "alam " yang tercipta didalamnya harus mendukung terjadinya kegiatan yang betul-betul mencapai tujuannya.

Observasi kelas adalah kunjungan yang dialakukan supervisor kesebuah kelas denagn maksud untuk mencermati situasi atau peristiwa yang sedang berlangsung di kelas yang bersangkutan.Pendapat lain mengatakan bahwa teknik supervisi pendidikan adalah alat yang digunakan oleh supervisor untuk mencapai tujuan supervisi itu sendiri yang pada akhirnya dapat melakukan perbaikan pengajaran yang sesuai dengan situasi dan kondisi. Kompetensi guru merupakan perpaduan antara kemampuan personalia, keilmuan, teknologi, sosial, dan spiritual yang membentuk kompetensi standar profesi guru, yang mencakup penguasaan materi, pemahaman terhadap peserta didik, pembelajaran yang mendidik, pengembangan pribadi dan profesionalitas. Kompetensi guru lebih merujuk pada kemampuan guru untuk mengajar dan mendidik sehingga menghasilkan perubahan perilaku belajar dari peserta didik. Kemampuan guru yang dimaksud adalah tidak hanya dari segi pengetahuan saja tetapi juga dari segi kepribadian, sosial dan profesional sebagai guru.

\section{Saran}

Saran yang dapat saya berikan adalah sebaiknya teknik observasi kelas terhadap guru lebih dilengkapi dengan instrument observasi agar penelitian atau observasi yang dilakukan kepala sekolah atau supervisor dapat lebih baik dan bisa mencapai tujuan yang diharapkan untuk kemajuan pendidikan di sekolah . Agar guru lebih bisa memperbaiki kesalahan atau kekurangan yang ada pada dirinya dalam mengajar di kelas selama proses pembelajaran. Seorang guru harus memiliki kompetensi yang telah ditetapkan agar tujuan pendidikan dapat tercapai dengan maksimal.

\section{KEPUSTAKAAN}

Arikunto, Suharsimi. 2004. Dasar-Dasar Supervisi. Jakarta : Rineka Cipta.

Aziza Nur Persia, dkk. (2013). "Peran Perpustakaan Anak Di Rumah Sakit Kanker Dharmais Jakarta”. Jurnal Ilmu Perpustakaan 2(3).

Darma, A. (2007). Manajemen Sekolah. Jakarta: Depdiknas.

Hadiyanto, H. 2004. Mencari Sosok Desentralisasi Manajemen

Pendidikan di Indonesia. Jakarta: Rineka Cipta.

Jamali, A., \& Prasojo, L. D. (2013). "Pengaruh Kompetensi Manajerial Kepala Sekolah, Lingkungan, Motivasi Guru, terhadap Prestasi Siswa SMA Muhammadiyah Kota Yogyakarta". Jurnal Akuntabilitas Manajemen Pendidikan, 1(1).

Masoumeh Zaare. (2013). "An Investigation Into The Effect of Classroom Obsevation on Teaching Methodology". Procedia Jounal, $1(2)$.

Mulyasa, Enco. 2013. Standar Kompetensi dan Sertifikasi Guru. Bandung: Remaja Rosdakarya.

Musfah, Jejen. 2015. Peningkatan Kompetensi Guru melalui Pelatihan dan Sumber Belajar Teori dan Praktik. Jakarta: Prenadamedia Group.

Pramita Surya,dkk. (2014). " Pelaksanaan Supervisi Observasi Kelas Kepala Sekolah Untuk Peningkatan Kinerja Guru". Jurnal Inspirasi Manajemen, 3(3).

Sagala, H. Syaiful. 2010. Supervisi Pembelajaran dalam Profesi Pendidikan. Cet. I. Bandung: Alfabeta”. 
Sahertian, Piet A. 2010. Konsep Dasar dan Teknik Supervisi Pendidikan dalam Rangka Pengembangan Sumber Daya Manusia, Cet. II. Jakarta: Rineka Cipta.

Shanjida. (2018). " Classroom Observation-A Powerfull Tool For Continuous Professional Development (CPD)". International Journal on Language, 2(2).

Sule, E. T., \& Saefullah, K. (2008). Pengantar Manajemen. Jakarta: Kencana Prenada Media Group.

Sunani (2014).Menggagas Supervisi kolega, alami, santai, dan terpokus.Jakarta : direktorat Pembinaan Pendidik dan Tenaga Kependidikan Pendidikan Dasar.

Tia Ayu Ningrum,dkk. (2019).“ Pembinaan Kompetensi Manajerial dan Supervisi Kepala Sekolah". Jurnal Halaqah, 1(4).

Yogaswara, A. (2010). "Kontribusi Manajerial Kepala Sekolah dan Sistem Informasi Kepegawaian terhadap Kinerja Mengajar Guru". Penelitian Pendidikan, 10(2). 